\title{
Mitochondrial DNA insertion polymorphism and germ line heteroplasmy in the Triturus cristatus complex
}

\author{
Graham P. Wallis*
}

\author{
Zoology Department, Leicester University, Leicester \\ LE1 7RH, U.K.
}

Restriction enzyme analysis of mitochondrial (mt) DNA isolated from oocytes of 185 individuals of the $T$. cristatus complex collected from 10 European countries has demonstrated that large length variation ( $>40$ bp) is a common feature of the group. Insertion polymorphism was found both within and among populations, and in all cases maps to the control region of the molecule. In addition, 2 individuals from Pisa, (Italy) were each found to be heteroplasmic for 2 large insertions comprising tandem repeats of 1100 bp of the control region. Large-scale length variation has been described in a few other lower vertebrates, but some of the insertion variants within populations described here are of unprecedented size (up to $8500 \mathrm{bp}$ ). This is in dramatic contrast to mammalian mtDNA in which size variation is largely restricted to small $(<15$ bp) insertions and deletions.

\section{INTRODUCTION}

Metazoan mitochondrial (mt) DNA has proved of great interest to evolutionary geneticists for several reasons. The supercoiled closed circular genome exhibits extreme economy of organisation, packing genes for 2 rRNAs, 22 tRNAs and 13 mRNAs into 15.7-19.5 kbp (Brown, 1985). The control region includes the D-loop, a triplex structure of essentially non-coding DNA containing a hybridised $\mathrm{H}$-strand fragment representing replication initiation. It is flanked upstream by the gene for tRNA ${ }^{\text {Pro }}$, and downstream by a non-coding region followed by the tRNA ${ }^{\text {Phe }}$ and 12S rRNA genes. The size of the maternally inherited $\mathrm{mt}$ genome varies little across related taxa, and the gene map is highly conserved. It has been widely shown that mammalian (and possibly all chordate) mtDNA evolves some $5-10 \times$ faster than nuclear DNA in terms of the rate of base substitution (Miyata et al., 1982; Cann et al., 1984; Brown, 1985), making it a highly informative molecule for the analysis of population structure and closely related taxa (Avise et al., 1979, 1983; Saunders et al., 1986). Although evolution of the $\mathrm{mt}$ genome proceeds

\footnotetext{
* Present Address: Zoology Department, University of Western Australia, Nedlands, WA 6009, Australia.
}

primarily by base substitution, with transition substitutions hugely outnumbering transversions (Brown, 1985; Hasegawa et al., 1985), there is growing evidence that insertion/deletion polymorphism occurs in natural populations (see Discussion). It is also becoming clear that not all individuals are homoplasmic, i.e. homogeneous for the same mt genotype throughout all body tissues; results from some species of animals now show that organisms may contain and transmit heterogeneous populations of mitochondria (e.g., Solignac et al., 1984). These findings have relied largely upon insertion polymorphism to permit unambiguous demonstration of heteroplasmy, as it is difficult to distinguish heterogeneity for presence and absence of restriction enzyme site(s) from possible partial digestion of mtDNA.

This paper documents several insertion polymorphisms occurring in populations of the great crested newt, Triturus cristatus. Some of these insertions are particularly large, in one case a reiteration of over 50 per cent of the entire mt genome, resulting in the largest recorded animal mt genome. Two instances of heteroplasmy are described that result from 2 - and 3-fold reiterations of $1100 \mathrm{bp}$ of DNA in the control region of the molecule. This paper also includes a simple method for the isolation and restriction enzyme analysis of amphibian mtDNA. 


\section{MATERIALS AND METHODS}

\section{Newts}

Triturus cristatus is found throughout Europe with the exception of south-west France and the Iberian peninsula. Four races/subspecies are currently recognised (Thorn, 1968): cristatus, the more northerly and most widely distributed form; carnifex, found south of the Italian Alps in Italy and east to the Dinaric Alps; dobrogicus, the slender Danube valley form found from Vienna to the Black Sea; karelinii, the larger south-east European form found from the Balkans to the Caucasus. While each of these subspecies is typified by certain coloration, pattern and body form, morphological variation among populations is marked. In Yugoslavia in particular, the carnifex / karelinii transition is not clear cut (Kalezić and Stevanović, 1980; pers. obs.). However, the disparity of the four subspecies for chromosome (e.g. Bucci-Innocenti et al., 1983; Macgregor and Sessions, 1986) and isozyme (Kalezić and Hedgecock, 1980; Frelow et al., submitted; Rafiński and Arntzen, submitted) markers has led some authors to ascribe specific status. Some of the population samples from Yugoslavia and Greece are not clearly classifiable, and are referred to as "carnifex".

Newts were captured from ponds, ditches and streams by repeated sweeping with hand-held nets, and transported at $4^{\circ} \mathrm{C}$. They were kept in aquaria and fed with chopped liver, earthworms and tubifex until required. Newts were immobilised in MS222 (ethyl m-aminobenzoate) solution for $10 \mathrm{~min}$, rinsed, photographed and measured before dissection.

\section{Mt DNA isolation}

A procedure simplified from Lansman et al., (1981) was developed to isolate amphibian oocyte mtDNA. Dissected ovaries were homogenised in $5 \mathrm{ml} \mathrm{MSTC}(210 \mathrm{mM}$ mannitol, $70 \mathrm{mM}$ sucrose, $50 \mathrm{mM}$ tris- $\mathrm{HCl} p \mathrm{H} 7 \cdot 5,3 \mathrm{mM} \mathrm{CaCl}{ }_{2}$ ) with 6-8 strokes of a Dounce homogeniser. $0.5 \mathrm{M}$ EDTA $p \mathrm{H} 7.5$ was added to $10 \mathrm{mM}$, and nuclei and debris were removed by spinning down at $800 \mathrm{~g}$ for $2 \times$ $10 \mathrm{~min}$. Mitochondria were then pelleted at $20,000 \mathrm{~g}$ for $20 \mathrm{~min}$, resuspended in $15 \mathrm{ml}$ MSTE (MST, $10 \mathrm{mM}$ EDTA), repelleted, resuspended in $2.3 \mathrm{ml}$ STE $(100 \mathrm{mM} \mathrm{NaCl}, 50 \mathrm{mM}$ tris- $\mathrm{HCl}, 10 \mathrm{mM}$ EDTA, $p \mathrm{H} \mathrm{7.5)}$ and lysed by the addition of $100 \mu \mathrm{l}$ 20 per cent SDS. After adding $250 \mu \mathrm{g}$ of RNAse $A$ and 250 units of RNAse $\mathrm{Tl}$ to the lysate, it was incubated at $37^{\circ} \mathrm{C}$ for $30 \mathrm{~min} .5$ units of proteinase
$K$ were added and incubation continued for up to 2 hours. An equal volume of phenol/chloroform $\left(100 \mathrm{~g}\right.$ phenol, $100 \mathrm{ml} \quad \mathrm{CHCl}_{3}, \quad 0 \cdot 1 \mathrm{~g} \quad$ hydroxyquinoline, $4 \mathrm{ml}$ isoamyl alcohol; stored under $10 \mathrm{mM}$ tris- $\mathrm{HCl} p \mathrm{H} 7.5$ at $4^{\circ} \mathrm{C}$ ) was added to the lysate, and mixed by pipette. After centrifuging at $2000 \mathrm{~g}$, the extraction process was repeated twice, and residual mtDNA was back-extracted

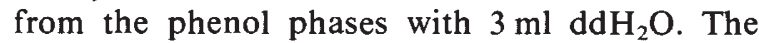
pooled supernatants were dialysed against TE (4 mM tris- $\mathrm{HCl}, 0.5 \mathrm{mM}$ EDTA; $p \mathrm{H} 8$ ) overnight, then with fresh TE for $2 \times 1 \mathrm{~h}$. MtDNA was precipitated by adding $2 \mathrm{M}$ sodium acetate to $0.2 \mathrm{M}$, mixing with 2 vol. of 100 per cent ethanol, cooling to $-80^{\circ} \mathrm{C}$, and spinning at $20,000 \mathrm{~g}$ for $30 \mathrm{~min}$. The

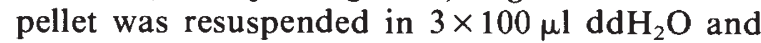
stored at $-20^{\circ} \mathrm{C}$. Amphibian oocytes are a particularly good source of mtDNA (Dawid and Blackler, 1972), this procedure yielding 1-3 $\mu \mathrm{g}$ mtDNA per gram of tissue.

\section{Digestion with restriction endonucleases}

Digestion of mtDNA was carried out under salt and temperature conditions appropriate to each enzyme as described by the manufacturer. Digests of $10-30 \mu \mathrm{l}$ were done in $1.5 \mathrm{ml}$ microfuge tubes, using $4 \mathrm{mM}$ spermidine trihydrochloride and large excesses of restriction enzyme to enhance complete digestion. Multiple digests were done concurrently if salt conditions were compatible, or sequentially followed by levelling of salt concentrations before electrophoresis. The following restriction enzymes (recognition sites) were used: BglII (A/GATCT), Cla I (AT/CGAT), EcoRI (G/AATTC), Eco RV (GAT/ATC), HindIII (A/AGCTT), Pst I (CTGCA/G), PvuII (CAG/CTG), SstII (CCGC/GG), StuI (AGG/CCT), XbaI (T/CTAGA), and XhoI (C/TCGAG). These were variously supplied by Amersham International, Bethesda Research Labs (BRL), New England Bio-Labs and Pharmacia. Reactions were stopped after at least $2 \mathrm{~h}$ by adding $1 / 10$ volume of loading buffer (30 per cent Ficoll, 0.5 per cent sarcosyl, $0 \cdot 1$ per cent bromophenol blue, $0 \cdot 1 \mathrm{M}$ EDTA pH 8).

\section{Agarose gel electrophoresis}

Fragments were sized in horizontal gels of 0.45 per cent to 2 per cent agarose, depending upon fragment size. A continuous tris-borate buffer ( $89 \mathrm{mM}$ tris, $73 \mathrm{mM}$ boric acid, $2.5 \mathrm{mM}$ EDTA; $p \mathrm{H} 8 \cdot 2$ ) was used with $0.7 \mu \mathrm{g} / \mathrm{ml}$ ethidium bromide added to the gel and anodal buffer. 
$20 \mathrm{~cm} \times 20 \mathrm{~cm}$ gels with 2 rows of 33 wells were run at $4-5 \mathrm{~V} / \mathrm{cm}$ for $2-4 \mathrm{~h}$, and photographed over UV light using type 55 positive-negative Polaroid film. A variety of preheated $\lambda$ digests and a $1 \mathrm{kbp}$ ladder (BRL) were used to provide fragments of known sizes and to enable graphical sizing of mtDNA fragments. This versatile marker permits accurate sizing of fragments; perhaps \pm 1 per cent given optimal running conditions.

\section{Restriction mapping}

All of the enzymes used in this study recognise hexanucleotide sequences, and thus produce small numbers of fragments which expedites mapping. To avoid ambiguities, most of the possible pairwise combinations (double digests) were used.

\section{RESULTS}

\section{Restriction fragment analysis}

Using enzymes that linearise the mtDNA circle by cleaving once, the normal size of the Triturus mt genome was estimated to be $16 \cdot 3$ to $16 \cdot 4 \mathrm{kbp}$. Linearised molecules were intermediate to the 15,721 bp Bam HI/Eco RI and 16,841 bp BamHI $\lambda$ fragments. Xenopus mtDNA linearised with Pst I was intermediate in size to the $17,053 \mathrm{bp} \mathrm{Kpn} \mathrm{I} \mathrm{and}$ 19,397 bp SmaI $\lambda$ fragments.

The 185 mtDNA samples were each analysed using all 11 of the restriction enzymes. The samples displayed a variety of length variants visible in several fragments. Table 1 gives details of length variation for every population analysed, using a HindIII fragment delimited by two conserved sites across all taxa. Smaller fragments produced by other enzymes were used to size insertions within populations more accurately, but restriction site variation prevented comparison of these fragments across taxa. The values given for the smaller length variations should only be taken as approximations.

Two population samples of cristatus displayed insertion polymorphism; 3 newts from Mayenne site 2 C9 had a 140 bp insertion (fig. 1) and 5 from Limanowa had a 45 bp insertion. For carnifex, newts supplied by "Xenopus Ltd." (probably from Milano) had $\mathrm{mt}$ genomes $140 \mathrm{bp}$ larger than those from Acerra, Pisa, Firenze and Kramplje. One of these possessed a $100 \mathrm{bp}$ insertion in addition to this difference, and 2 newts from Pisa were heteroplasmic for insertions of 2250 and 3350 bp (fig. 2). Populations of "carnifex" from eastern Yugoslavia south of Beograd possessed larger mt genomes

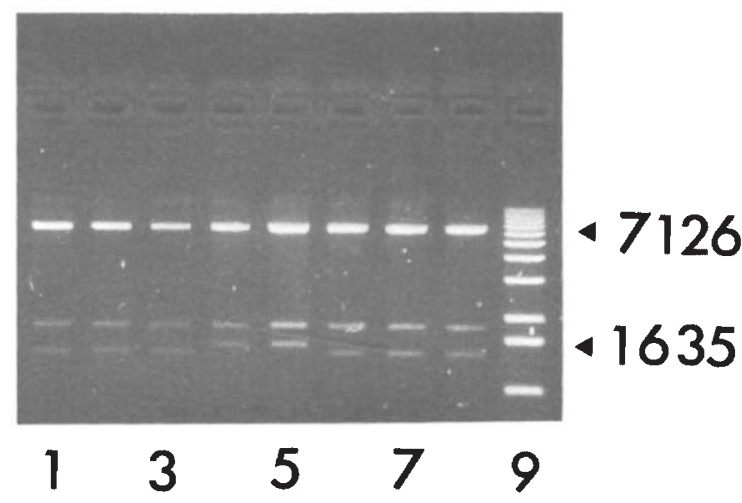

Figure 1 MtDNA of $T$. c. cristatus from Mayenne (France) digested with $P v u I I$ and run on a 0.9 per cent agarose gel. Lanes 1-3, normal profile; $4-5,140$ bp insertion; $6-8$, normal; 9, 1 kbp ladder marker (marker bands: 12216, 11198, $10180,9162,8144,7126,6108,5090,4072,3054,2036,1635$, $1018,516 / 506,394,344,298,220,200,154$ and $142 \mathrm{bp})$.

than neighbouring western Yugoslav and Italian populations of carnifex, and showed considerable differentiation for restriction site variation (unpubl. data). Two newts from Trešnja possessed insertion polymorphisms of 100 and $140 \mathrm{bp}$ in addtion to the interpopulation difference, and three newts from Guberevac had $70 \mathrm{bp}$ larger genomes (fig. 3). Some of the newts from Trešnja and Guberevac had slightly fuzzy control region bands which might indicate heteroplasmy for small continuously distributed insertions. Newts from Ano Kaliniki (just inside the northern border of Greece) were more like Italian carnifex populations for mtDNA restriction fragments profiles, and shared the HindIII fragment typical of those populations. MtDNA from one newt, however, contained extra bands for all digests revealing an insertion of unprecedented size, about $8500 \mathrm{bp}$, producing a $\mathrm{mt}$ genome of nearly $25 \mathrm{kbp}$ (fig. 4). This is the largest recorded metazoan mt genome; Kessler and Avise (1985) mention large interspecific size differences in Hyla. The size of the HindIII fragment in dobrogicus was smaller than in the other subspecies, with no size variation observed.

Thus there is evidence for mtDNA length variation (1) among subspecies (2) among populations within subspecies (3) among individuals within populations (4) within individuals.

\section{Restriction fragment mapping}

The locations of insertions were determined by mapping representative cristatus and carnifex mt genomes (fig. 5); map positions of the StuI sites have not been determined. Maps were aligned with 
Table 1 MtDNA insertion polymorphism in Triturus cristatus sub-species as shown by the variable sized HindII fragment

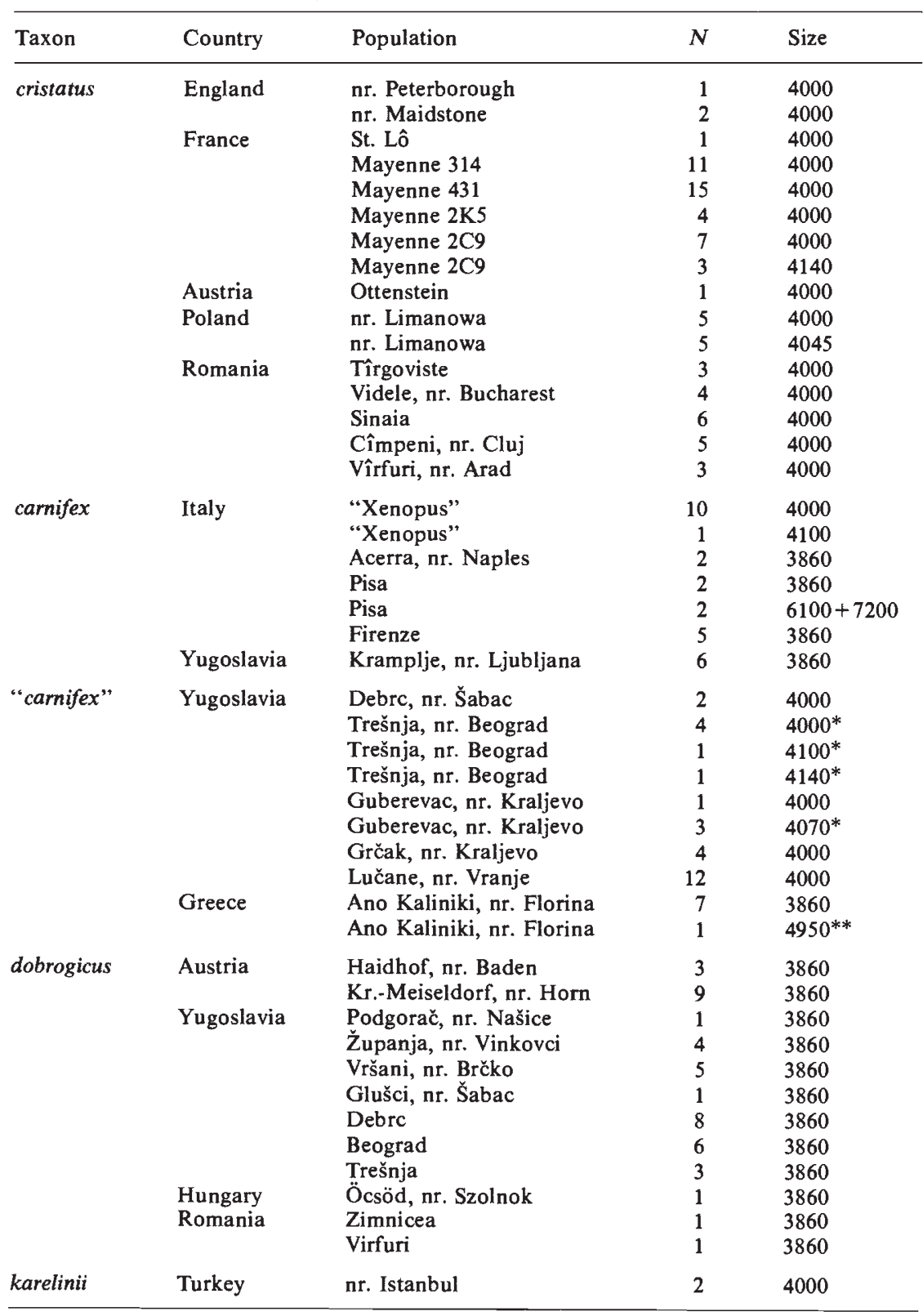

* fuzzy bands (see text)

$* *$ the $\sim 8.5 \mathrm{kbp}$ insertion in this sample included two HindIII sites, producing a double $3540 \mathrm{bp}$ band also (see text)

the mammalian map using the two highly conserved Sst II sites, one occurring in each rRNA gene. These two sites delimit fragments of $1672 \mathrm{bp}$ in Homo (Anderson et al., 1981), 1688 bp in Bos (Anderson et al., 1982), $1690 \mathrm{bp}$ in Mus (Bibb et al., 1981), 1700 bp in Xenopus (Cordonnier et al., 1982) and $1750 \mathrm{bp}$ in Salmo (Berg and Ferris,
1984). These correspond to a $1625 \mathrm{bp}$ fragment in Triturus. The Xenopus mt genome is co-linear with the mammalian genome (Champagne et al., 1984) and most probably with the caudate genome also; indeed, it seems likely that all vertebrate $\mathrm{mt}$ genomes are co-linear (Araya et al., 1984). Orientation of the newt genomes against Xenopus was 


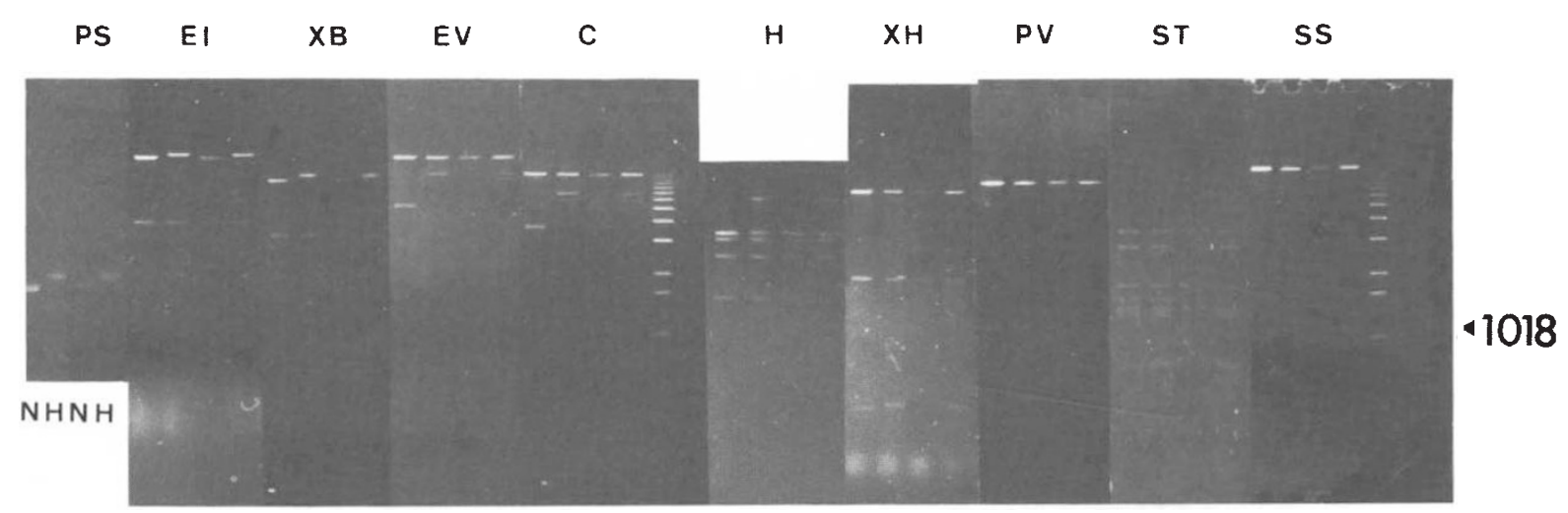

Figure 2 Composite of mtDNA of $4 T$. c. carnifex individuals from Pisa (Italy) digested with a range of restriction enzymes and run on $0.8-0.9$ per cent agárose gels. Each block of 4 comprises 2 normal $(\mathrm{N})$ and 2 insertion heteroplasmic (H) individuals. Blocks are aligned by origin position; run times vary among blocks. Restriction enzymes used are (left to right): Pst I, Eco RI, $X b a I$, EcoRV, ClaI, HindIII, XhoI, PvuII, StuI and SstII (see text for explanation). The $1 \mathrm{kpb}$ marker (see fig. 1) is included for ClaI and SstII.

determined by the conserved ClaI, HindIII and $\mathrm{Xba}$ I sites. Mt genome sizes of $17 \cdot 4 \mathrm{kbp}$ (Cordonnier et al., 1982) and $17.7 \mathrm{kbp}$ (Brown, 1983; Carr, 1983) have been reported for Xenopus. This is some 6-8 per cent larger than Triturus, a fact largely accounted for by the longer control region.

The cristatus insertions were visible in the EcoRV 3470, HindIII 4000 and PvuII 1450 fragments containing the control region (fig. 1), and in the StuI 3700 fragment.

All carnifex length variation was detectable in Eco RV 3330, HindIII 3860 and PvuII 2080 fragments containing the control region, and in the StuI 1710 fragment. The large insertions in the two newts from Pisa were visible in every digest (fig. 2). The large fragment was enlarged in the case of Pst I 16,300, Eco RI $\sim 13,600$ and $X b a \mathrm{I} \sim 12,300$ fragments. This was also the case for EcoRV 3330 , ClaI 3700 and HindIII 3860, only here the two insertion length variants were clearly resolved. For XhoI, PvuII, StuI and SstII, intense bands of $1100 \mathrm{bp}$ were observed in addition to the usual profile. Hence it may be concluded that the insertions of 2250 and $3350 \mathrm{bp}$ are tandem repeats of $1100 \mathrm{bp}$, each containing the XhoI, PvuII and Sst II sites in the region of the origin of $\mathrm{H}$-strand replication (fig. 5), and a $S t u$ I site. One newt contained approximately equal proportions of the the 2 insertion variants in its oocyte mtDNA; in the other the $3350 \mathrm{bp}$ insertion clearly predominated.

In "carnifex", length variation was evident in HindIII 4000, PvuII 3300 and StuI 3460 fragments (fig. 3), once again implicating the control region as the site of insertion. The newt from Ano Kaliniki with a particularly large insertion had large fragments BglII $\sim 16,300$, XhoI $\sim 16,300$ and EcoRI $\sim 13,600$ of greatly increased size (fig. 4). For Pst $\mathrm{I}$, $P v u$ II, Cla I and Eco RV, there was a new fragment of $\sim 8500 \mathrm{bp}$ in addition to the normal profile. The other four enzymes gave more complex patterns each involving a single new fragment and duplicated normal fragments: Sst II gave a new $\sim 6700$ fragment and a double 1625 fragment, $X b a I$ a new 4600 fragment and a double 4000 fragment, HindIII a new 4950 fragment and a double 3540 fragment, and StuI a new 1440 fragment and double 3370,1780 and 1710 fragments. Thus this insertion is a single duplication of the sequence of sites: Pvu II - Eco RV-Hind III - Sst II - Cla I - Xba I - Sst II HindIII-Pst I-XbaI, including the $12 \mathrm{~S}, 16 \mathrm{~S}$, N1 and N2 genes (fig. 5; this population does not have the XhoI and Sst II sites nearest the origin of $\mathrm{H}$-strand replication, or the HindIII and PvuII sites in the COI and COII genes).

None of the newts displaying intrapopulation insertion polymorphism, were in any way morphologically distinct from other members of that population.

\section{DISCUSSION}

In an extensive study of 112 humans, Cann and Wilson (1983) described 14 length variants ranging from -6 to +14 bp occurring in 9 regions of the mtDNA circle. Horai and Matsunaga (1986) examined 116 Japanese and found at least 4 variants of -7 to $+14 \mathrm{bp}$, plus a possible $80 \mathrm{bp}$ insertion. Additionally, every individual possessed a $60 \mathrm{bp}$ insertion relative to the Cambridge sequence (Anderson et al., 1981). In a study of 899 bp of the D-loop regions in 7 humans, Aquadro 


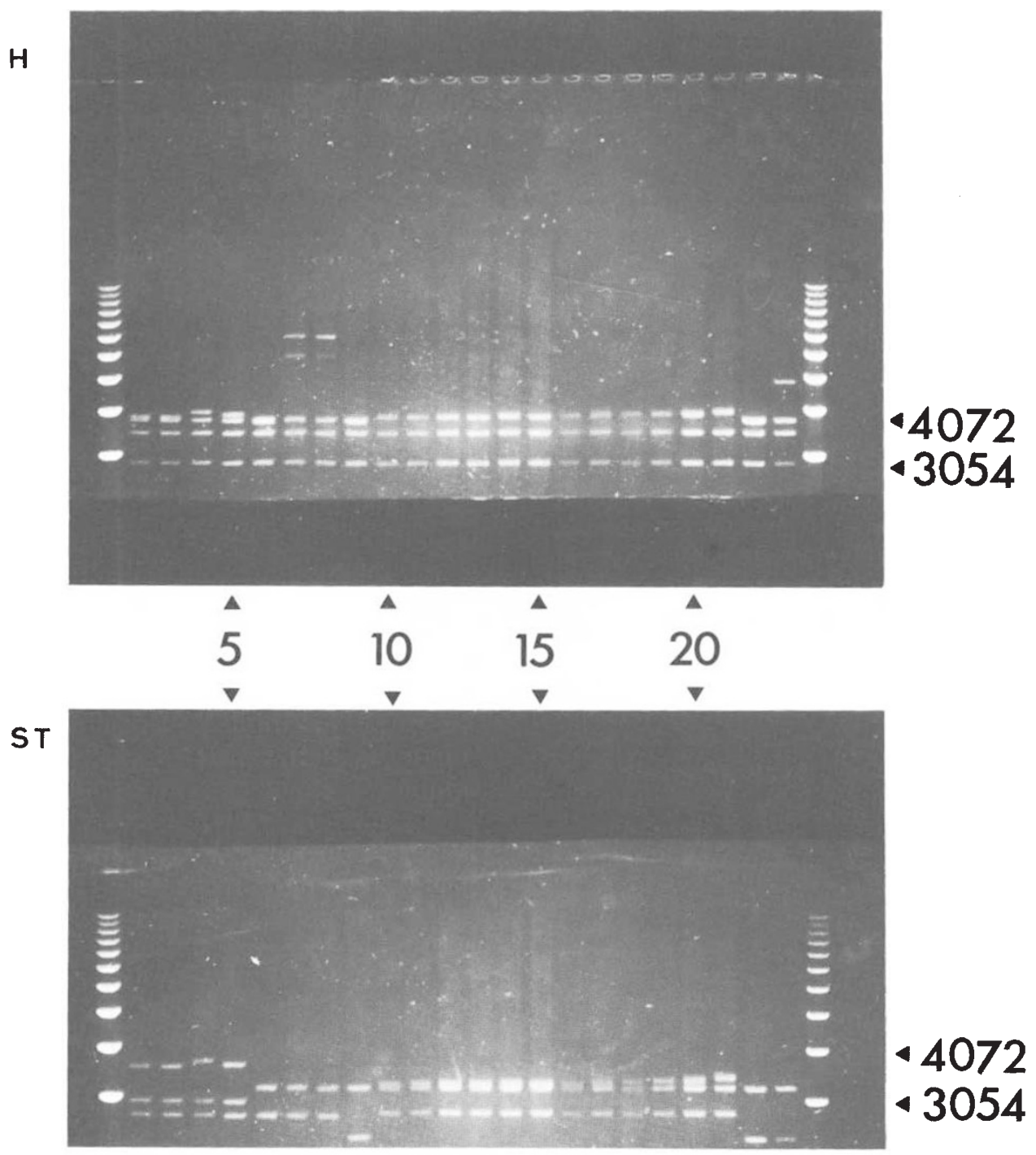

Figure 3 MtDNA of T. cristatus subspp. individuals digested with HindIII and StuI, and run on $0 \cdot 5$ per cent agarose gels to show mobility differences due to variation in length of the control region fragments (see table 1). The $1 \mathrm{kbp}$ marker (see fig. 1 ) is in the end lanes; other lanes are as follows, giving the size of the HindIII large fragment: cristatus: 2, 4000 bp Mayenne; 3, $4000 \mathrm{bp}$ Limanowa; 4, 4140 bp Mayenne; 5, 4045 bp Limanowa. carnifex: 6, 3860 bp Pisa; 7-8, 6100+7200 bp Pisa; 9 , 3860 bp Kramplje. "carnifex": 10, 4000 bp Lučane; 11, 4000 bp Grčak; 12-15, 4000 bp Trešnja; 16, 4000 bp Guberevac; 17-19, 4070 bp Guberevac; 20 , 4100 bp Trešnja; 21, 4140 bp Trešnja; 22, 3860 bp Ano Kalinki; 23, 4950 bp Ano Kalinki. Fragments much smaller than 3000 bp have run off the gels.

and Greenberg (1983) and Greenberg et al. (1983) describe 5 small length variations amounting to nearly 9 per cent of the total variation observed. Brown and DesRosiers (1983) describe length variation in homopolymer runs of up to $4 \mathrm{bp}$ between tRNA $^{\text {Cys }}$ and $t$ RNA $^{\text {Tyr }}$ near the origin of L-strand replication in Rattus, and similar findings are reported in the D-loops of cows (Hauswirth et al., 1984) and humans (Hauswirth and Clayton, 1985). A study of 208 individuals representing 8 species of Mus revelaed only one insertion variant: $12 \mathrm{bp}$ (in or near the D-loop) in a single mouse (Ferris et al., 1983). Surveys of 87 Geomys pinetus (Avise et al., 1979) and 135 Peromyscus maniculatus (Lansman et al., 1983), and a bird study (Kessler and Avise, 1985) have revealed no length variation polymorphism, although small variations could have gone undetected.

These findings contrast with those from insects, which possess a hypervariable $\mathrm{A}+\mathrm{T}$ rich region overlapping the origin of replication (Clary and Wolstenholme, 1984) containing insertions of 


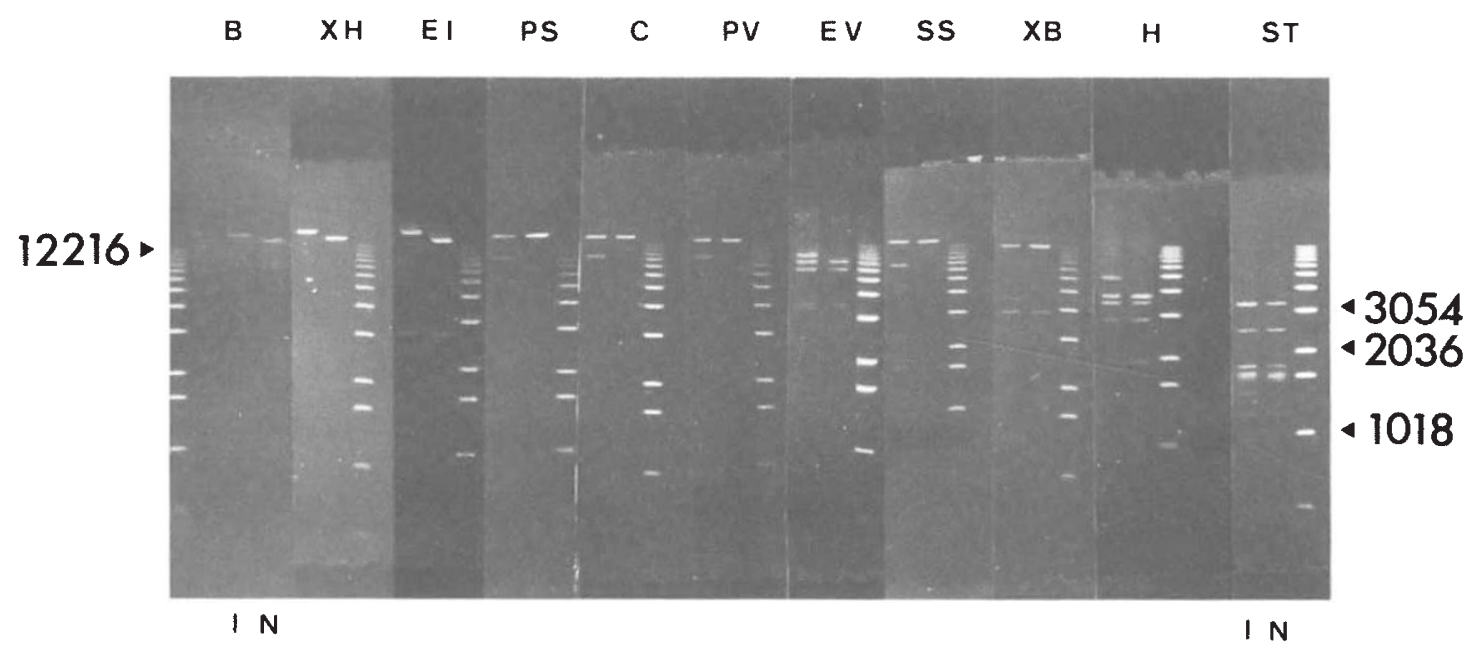

Figure 4 Composite of mtDNA of 2T. c. "carnifex" individuals from Ano Kaliniki (Greece) digested with a range of restriction enzymes. Each strip comprises the profile of the individual containing the $\sim 8.5 \mathrm{kbp}$ insertion (I), the normal profile ( $\mathrm{N}$ ), and the $1 \mathrm{kbp}$ ladder marker (see fig. 1). Restriction enzymes used are (left to right): BglII, XhoI, Eco RI, PstI, ClaI, PvuII, Eco RV, SstII, XbaI, HindIII and StuI (see text for explanation).
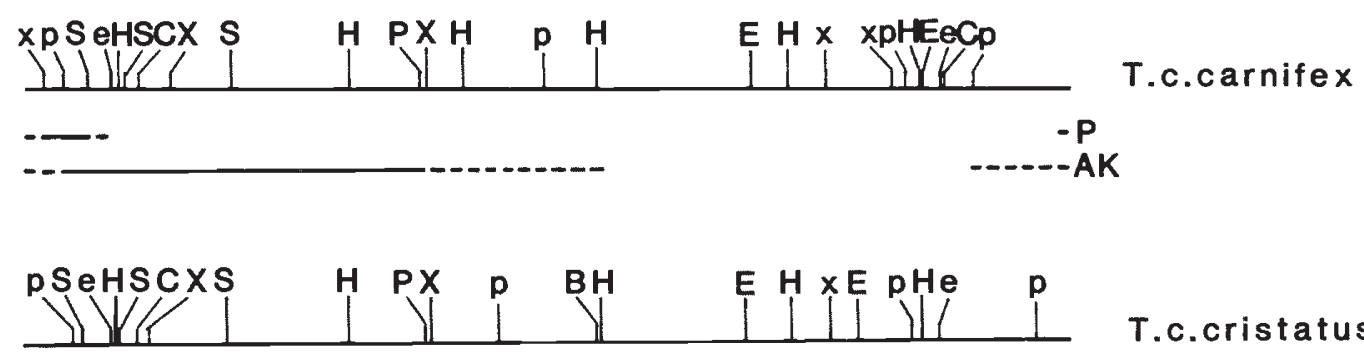

T.c.cristatus

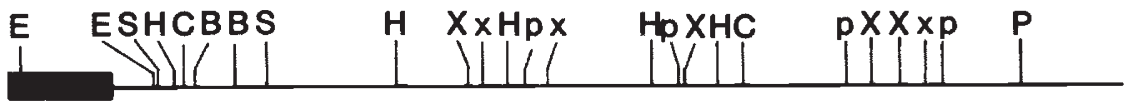

X.Iaevis

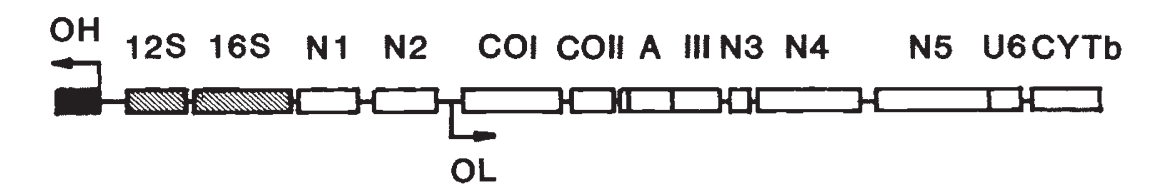

H.sapiens

\begin{tabular}{|c|c|c|c|c|c|c|c|c|}
\hline 17 & $T$ & T & $T$ & $T$ & $T$ & $T$ & $T$ & 7 \\
\hline 2 & 4 & 6 & 8 & 10 & 12 & 14 & 16 & kbp \\
\hline
\end{tabular}

Figure 5 Restriction maps for three amphibian mtDNAs aligned against the human gene map (Anderson et al., 1981). Shaded boxes represent the D-loop, hatched boxes rRNA genes, and empty boxes polypeptide coding genes. These are interspersed with tRNA genes, the origin of light-strand replication, and a few non-coding bases. The large duplicated region in newts from Pisa and Ano Kaliniki are represented by solid and dashed lines, indicating definite and possible extents of the duplications respectively. Enzyme sites are indicated by letters according to the following code: BglII, B; Cla I, C; EcoRI, E; EcoRV, e; HindIII, H; PstI, P; PvuII, p; SstII, S; XbaI, X; XhoI, x. 
several hundred base pairs within a number of species (Reilly and Thomas, 1980; Fauron and Wolstenholme, 1980; Solignac et al., 1983; Harrison et al., 1985). Recent findings in Cnemidophorus lizards (Densmore et al., 1985; Mortiz and Brown, 1986), Ranid (Monnerot et al., 1984) and Hylid (Bermingham et al., 1986; Spolsky and Uzzell, 1986) frogs, and bowfin fish (Bermingham et al., 1986), suggest that these groups also differ from mammals, not only in the abundance of large insertions, but by displaying heteroplasmy for many of these (table 2). Studies on other fish (Avise and Saunders, 1984; Gyllenstein et al., 1985) and Xenopus (Carr, 1983) have not, however, disclosed such variation. In this paper, all the insertion polymorphism and heteroplasmy has been shown in oocyte mtDNA alone; there may prove to be higher levels if other organs were examined, but as these genomes are not transmitted they are not of direct relevance to evolution of the $\mathrm{mt}$ genome. Low levels of heteroplasmy (say $<5$ per cent) will also go undetected given the conditions of the study.

Large insertions therefore appear to be a recurrent feature of amphibian (and possibly reptilian and fish) mtDNA. This is in contrast to findings in mammals, in which even the largest length variations do not approach the size of many amphibian and insect insertions. Moreover, in the poikilothermic groups, considerable within population polymorphism is found. There are several factors that might impinge upon the prevalence of insertion polymorphism and heteroplasmy in natural populations: at the molecular level, the rate of generation of molecules carrying insertions; at the cellular level, the effective number of $\mathrm{mt}$ genomes per cell, the number of cell generations per germ line generation and degree of paternal leakage; at the population level, population size and migration rates. Additionally, selection can act at any level (for a theoretical treatment see, e.g. Birky et al., 1983; Takahata, 1984). Mt genomes made unnecessarily larger by the presence of insertions may be at a replicative disadvantage compared to those containing normal sized genomes, but the small amount of work done addressing this possibility suggests little or no deterministic sorting (Solignac et al., 1984). The "half-life" of $300 \mathrm{bp}$ insertion heteroplasmy in a Drosophila mauritiana isofemale line is of the order of 60 generations (Solignac et al., 1983), and complete sorting out may require as many as 500 generations (Solignac et al., 1984).

The explanation for the disparity among groups with regard to prevalence of insertion polymorphism seems likely to lie in differences in molecular mechanisms governing replication and repair of the mitochondrial genome, and/or sequence difference and their specific effects, resulting in disparate mutation rates. In Triturus cristatus, all length variation described maps to the control region, and where it has been possible to determine the nature of insertions, they are tandem duplications. These may result from strand slippage and mismatching during replication (Densmore et al., $1985)$; in the absence of sequence data, it is not possible to say whether or not there are shared end points. The fuzzy bands observed in some Trešnja and Guberevac samples imply that these newts were heteroplasmic for a continuous distribution of small length variations of $1-15 \mathrm{bp}$, as found in the conserved sequence blocks (CSBs) of mammals (Hauswirth et al., 1984; Hauswirth and Clayton, 1985). This parallels findings in Rana in which fuzziness over a 400-700 bp range has been described (Monnerot et al., 1984). The CSBs can be drawn into large hairpin structures, and may be related to insertion polymorphism in the region. Repeat sequences of 45 bp separated by 16 bp have

Table 2 Examples of heteroplasmy for mtDNA in animal populations showing \% individuals heteroplasmic

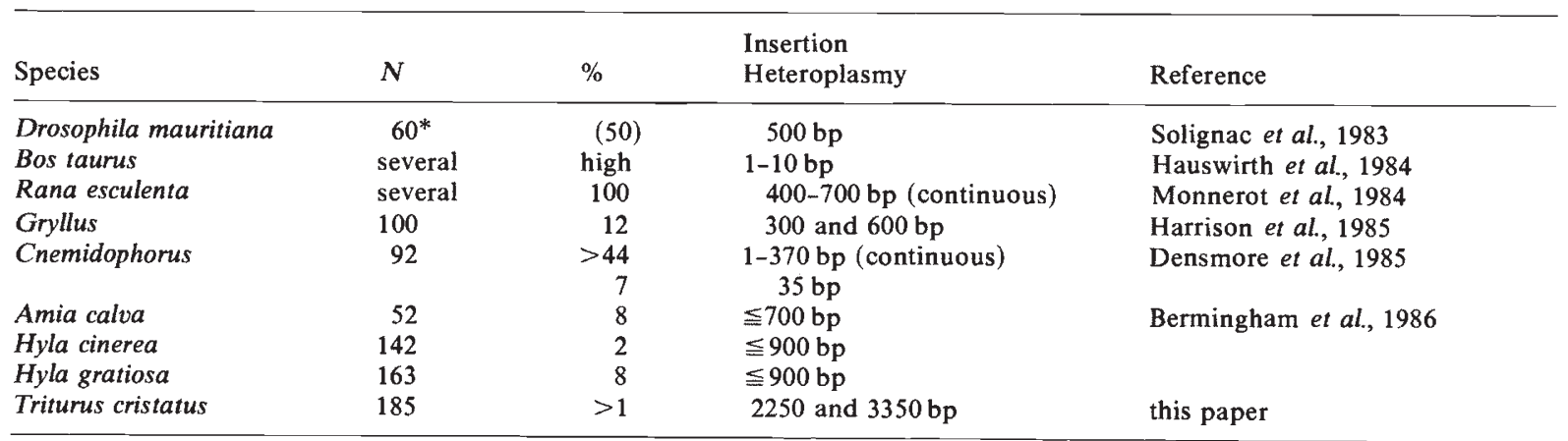

* 30th generation of isofemale line. 
been found within the Xenopus D-loop (Wong et al., 1983); such features could also promote the tendency for length variation in Triturus and indeed Amphibia as a whole. The prevalence of length variation in this region also results from it being mainly non-coding and a comparatively large target sequence $(>1 \mathrm{kbp})$.

It is interesting that in the case of Cnemidophorus it is the interspecific triploids that show highest frequency of insertions. In Triturus, one of the samples containing insertions and blurred control region bands (Trešnja) also displays evidence of intersubspecific cytoplasmic gene flow and possibly some nuclear gene flow (unpubl. data). Similarly, low levels of nuclear gene flow have been found between $T$. cristatus and T. marmoratus in the Mayenne department of France (Arntzen, 1986) where 2C9 cristatus display insertion polymorphism. It is thus tempting to speculate that presence of foreign genes may in some way "destabilise" the mt genome, whose replication is mediated by many nuclear gene products. This cannot be the whole story as some insertion polymorphism in T. cristatus occurs away from "subspecies" transition zones, but the effect may none the less exist.

The phenomenon of length variation has to be taken into account when analysing mtDNA restriction fragment profiles. It is important to distinguish this type of variation from site variation before making estimates of nucleotide divergence and inferring phylogeny. When considering fine-scale genetic differentiation, the problem of convergence may be lower for large scale length variation than for restriction site variation; each length variant is of a certain size and at a specific site in the $\mathrm{mt}$ genome, whereas restriction sites may "blink" off and on. Length variants have been useful in revealing population subdivision (Horai and Matsunaga, 1986; this paper), and have provided variation where restriction site variation is limited (Densmore et al., 1985). They therefore have potential as markers in studies of the genetic structure of natural populations.

Acknowledgements. This work was funded by SERC GR/C/05250, NERC GR3/5445, and a Royal Society Overseas Research Grant; their support is gratefully acknowledged. I thank Lise Baldwin, Wes Brown, Terry Burke and Craig Moritz for their helpful comments, and Herbert Macgregor for his support and provision of lab. facilities. I also thank Pim Arntzen, Lise Baldwin, Giuseppina Barsacchi-Pilone, Terry Burke, Deryk Frazer, Günter Gollman, Miloš Kalezic, Benedetto Lanza, Ettore Olmo, Slane Peterlin, Andrew Quayle, Jan Rafiński and Jana Vidić for their help in collection of newts.

\section{REFERENCES}

ANDERSON, S., BANKIER, A. T., BARRELL, B. G., DE BRUIJN M. H. L., COULSON, A. R., DROUIN, J., EPERON, I. C., NIERLICH, D. P., ROE, B. A., SANGER, F., SCHREIR, P. H., SMITH, A. J. H., STADEN, R. AND YOUNG, I. G. 1981. Sequence and organization of the human mitochondrial genome. Nature, $290,457-465$.

ANDERSON, S., DE BRUIJN, M. H. L., COULSON, A. R., EPERON, I. C., SANGER, F. AND YOUNG, I. G. 1982. Complete sequence of bovine mitochondrial DNA. J. Mol. Biol., 156, 683-717.

AQUADRO, C. F. AND GREENBERG, B. D. 1983. Human mitochondrial DNA variation and evolution: analysis of nucleotide sequences from seven individuals. Genetics, 103, 287-312.

ARAYA, A., AMTHAUER, R., LEON, G. AND KRAUSKOPF, M. 1984. Cloning, physical mapping and genome organization of mitochondrial DNA from Cyprinus carpio oocytes. Mol. Gen. Genet., 196, 43-52.

ARNTZEN, J. W. 1986. Aspects of introgressive hybridization in crested and marbled newts (Amphibia: Caudata). Preliminary results. In Studies in Herpetology. Prague. In press.

AVISE, J. C., GIBLIN-DAVIDSON, C., LAERM, J., PATTON, J. C. AND LANSMAN, R. A. 1979. Mitochondrial DNA clones and matriarchal phylogeny within and among geographic populations of the pocket gopher, Geomys pinetis. Proc. Natl. Acad. Sci. USA, 76, 6694-6698.

AVISE, J. C., SHAPIRA, J. F., DANIEL, S. W., AQUADRo, C. F. AND LANSMAN, R. A. 1983. Mitochondrial DNA differentiation during the speciation process in Peromyscus. Mol. Biol. Evol., 1, 38-56.

AVISE, J. C. AND SAUNDERS, N. C. 1984. Hybridization and introgression among species of sunfish (Lepomis): analysis by mitochondrial DNA and allozyme markers. Genetics, 108, 237-255.

BERG, W. J. AND FERRIS, S.D. 1984. Restriction endonuclease analysis of salmonid mitochondrial DNA. Can. J. Fish. Aquat. Sci., 41, 1041-1047.

BERMINGHAM, E., LAMB, T. E. AND AVISE, J. C. 1986. Size polymorphism and heteroplasmy in the m:ochondrial DNA of lower vertebrates. J. Hered., 77, 249-252.

BIBB, M. J., VAN ETTEN, R. A., WRIGHT, C. T., WALBERG, M W. AND CLAYTON, D. A. 1981. Sequence and gene organization of mouse mitochondrial DNA. Cell, 26, 167-180.

BIRKY, C. W., MARUYAMA, T. AND FUERST, P. 1983. An approach to population and evolutionary genetic theory for genes in mitochondria and chloroplasts, and some results. Genetics, 103, 513-527.

BROWN, G. G. AND DESROSIERS, L. J. 1983. Rat mitochondrial DNA polymorphism: sequence analysis of a hypervariable site for insertions/deletions. Nucl. Acids Res., 11, 66996708.

BROWN, W. M. 1983. Evolution of animal mitochondrial DNA Nei, M. and Koehn, R. K. (eds) In Evolution of Genes and Proteins. Sinauer, Sunderland MA, pp. 62-88.

BROWN, W. M. 1985. The mitochondrial genome of animals. Macintyre, R. J. (ed.) In Molecular Evolutionary Genetics, Plenum New York, pp. 95-130.

BUCCI-INNOCENTI, S., RAGGHIANTI, M. AND MANCINO, G. 1983. Investigations of karyology and hybrids in Triturus boscai and $T$. vittatus, with a reintcrpretation of the species groups within Triturus (Caudata: Salamandridae). Copeia, 1983, 662-672.

CANN, R. L. AND WILSON, A. C. 1983. Length mutations in human mitochondrial DNA. Genetics, 104, 699-711. 
CANN, R. L., BRoWN, W. M. AND Wilson, A. C. 1984. Polymorphic sites and the mechanism of evolution in human mitochondrial DNA. Genetics, 106, 479-499.

CARR, S. E. 1983. Genetics and evolution of mitochondrial DNA in Xenopus (Pipidae). Ph.D. thesis, University of California, Berkeley.

CHAMPAGNE, A-M., DENNEBOUY, N., JULIEN, J-F., LEHEGARAT, J-C. AND MOUNOLOU, J-C. 1984. Co-linear organization of Xenopus laevis and mouse mitochondrial genomes. Biochem. Biophys. Res. Commun., 122, 918-924.

ClaRY, D. O. AND WOLSTENHOLME, D. R. 1984. The Drosophila mitochondrial genome. Maclean, N. (ed.) In Oxford Surveys on Eukaryotic Genes, 1, Oxford Univ. Press, pp. 1-35.

CORDONNIER, A. M., VANNIER, P. A. AND BRUN, G. M. 1982. A restriction map of Xenopus laevis mitochondrial DNA. Eur. J. Biochem., 126, 119-127.

DAWID, I. B. AND BLACKLER, A. W. 1972. Maternal and cytoplasmic inheritance of mitochondrial DNA in Xenopus. Develop. Biol., 29, 152-161.

DENSMORE, LL. D., WRIGHT, J. W. AND BROWN, W. M. 1985 Length variation and heteroplasmy are frequent in mitochondrial DNA from parthenogenetic and bisexual lizards (genus Cnemidophorus). Genetics, 110, 689-707.

FAURON, C. M-R. AND WOLSTENHOLME, D. R. 1980. Intraspecific diversity of nucleotide sequences within the adenine thymine rich region of mitochondrial DNA molecules of Drosophila mauritiana, Drosophila melanogaster and Drosophila simulans. Nucl. Acids Res., 8, 5391-5409.

FERRIS, S. D., SAGE, R. D., PRAGER, E. M., RITTE, U. AND WILSON, A. C. 1983. Mitochondrial DNA evolution in mice. Genetics, 105, 681-721.

FRELOW, M., MACGREGOR, H. C. AND WAKE, D. B. 1986 Genetic differentiation among newts of the genus Triturus in western Europe. Submitted.

GREENBERG, B. D., NEWBOLD, J. E. AND SUGINO, A. 1983. Intraspecific nucleotide sequence variability surrounding the origin of replication in human mitochondrial DNA. Gene, 21, 33-49.

GYLLENSTEIN, U., LEARY, R. F., ALLENDORF, F. W. AND WILSON, A. C. 1985. Introgression between two cutthroat trout subspecies with substantial karyotypic, nuclear and mitochondrial genomic divergence. Genetics, 111, 905-915.

HARRISON, R. G., RAND, D. M. AND WHEELER, W. C. 1985. Mitochondrial DNA size variation within individual crickets. Science, 228, 1446-1448.

HASEGAWA, M., KISHINO, H. AND YANO, T. 1985. Dating of the human-ape splitting by a molecular clock of mitochondrial DNA. J. Mol. Evol., 22, 160-174.

HAUSWIRTH, W. W., VAN DE WALLE, M. J., LAIPIS, P. J. AND OLIVO, P. D. 1984. Heterogeneous mitochondrial DNA D-loop sequences in bovine tissue. Cell, 37, 1001-1007.

HAUSWIRTH, W. W. AND CLAYTON, D. A. 1985. Length heterogeneity of a conserved D-loop sequence in human mitochondrial DNA. Nucl. Acids Res, 13, 8093-8104.

HORAI, S. AND MATSUNAGA, E. 1986. Mitochondrial DNA polymorphism in Japanese II Analysis with restriction enzymes of four or five base pair recognition. Hum. Genet., $72,105-117$.

KALEZIĆ, M. L. AND HEDGECOCK, D. 1980. Genetic variation and differentiation of three common European newts (Triturus) in Yugoslavia. Br. J. Herpetol., 6, 49-57.
KALEZIĆ, M. L. AND STEVANOVIĆ, A. M. 1980. Morphologica. variation in the Crested Newt, Triturus cristatus (Urodela, Amphibia) from Kruševačka Župa (Central Serbia). Bio sistematika, 6, 69-80.

KESSLER, L. G. AND AVISE, J. C. 1985. A comparative description of mitochondrial DNA differentiation in selected avian and other vertebrate genera. Mol. Biol. Evol., 2, 109-125.

LANSMAN, R. A., SHADE, R. O., SHAPIRA, J. F. AND AVISE, J. C. 1981. The use of restriction endonucleases to measure mitochondrial DNA sequence relatedness in natural populations. III. Techniques and potential applications. J. Mol. Evol., 17, 214-226.

LANSMAN, R. A., AVISE, J. C., AQUADRO, C. F., SHAPIRA, J. F. AND DANIEL, S. W. 1983. Extensive genetic variation in mitochondrial DNA's among geographic populations of the deer mouse, Peromyscus maniculatus. Evolution, 37 1-16.

MACGREGOR, H. C. AND SESSIONS, S. K. 1986. The biological significance of variation in satellite DNA and heterochromatin in newts of the genus Triturus: an evolutionary perspective. Phil. Trans. R. Soc. Lond. B, 312, 243-259.

MIYATA, T., HAYASHIDA, H., KIKUNO, R., HASEGAWA, M. KOBAYASHI, M. AND KOIKE, K. 1982. Molecular clock of silent substitution: at least six-fold preponderance of silent changes in mitochondrial genes over those in nuclear genes. J. Mol. Evol., 19, 28-35.

MONNEROT, M., MOUNOLOU, J-C. AND SOLIGNAC, M. 1984. Intra-individual length heterogeneity of Rana esculenta mitochondrial DNA. Biol. Cell. 52, 213-218.

MORITZ, C. AND BROWN, W. M. 1986. Tandem duplication of D-loop and ribosomal RNA sequences in lizard mitochondrial DNA. Science, in press.

RAFIŃSKI, J. AND ARNTZEN, J. W. 1986. Biochemical systematics of the Old World newts, genus Triturus: allozyme data. Submitted.

REILLY, J. G. AND THOMAS, C. A. 1980. Length polymorphisms, restriction site variation, and maternal inheritance of mitochondrial DNA of Drosophila melanogaster. Plasmid, 3, 109-115

SAUNDERS, N. C., KeSSlER, L. G. AND AVISE, J. C. 1986 Genetic variation and geographic differentiation in mitochondrial DNA of the horseshoe crab, Limulus polyphemus. Genetics, 112, 613-627.

SOLIGNAC, M., MONNEROT, M. AND MOUNOLOU, J-C. 1983. Mitochondrial DNA heteroplasmy in Drosophila mauritiana. Proc. Natl. Acad. Sci. USA, 80, 6942-6946.

SOLIGNAC, M., GÉNEREMONT, J., MONNEROT, M. AND MOUNOLOU, J-C. 1984. Genetics of mitochondria in Drosophila: mtDNA inheritance in heteroplasmic strains of D. mauritiana. Mol. Gen. Genet., 197, 183-188.

SPOLSKY, C. AND UZZELL, T. 1986. Evolutionary history of the hybridogenetic frog Rana esculenta as deduced from mtDNA analyses. Mol. Biol. Evol., 3, 44-56.

TAKAHATA, N. 1984. A model of extranuclear genomes and the substitution rate under within-generation selection. Genet. Res., Camb., 44, 109-116.

THORN, R. 1968. Les salamandres d'Europe, d'Asie et d'Afrique $d u$ Nord. Lechevalier, Paris.

WONG, J. F. H., MA, D. P., WILSON, R. K. AND ROE, B. A. 1983. DNA sequence of the Xenopus laevis mitochondrial heavy and light strand replication orgins and flanking tRNA genes. Nucl. Acids Res., 11, 4977-4995. 